\title{
ZNACZENIE INSTRUMENTÓW RACHUNKOWOŚCI WSPOMAGAJACCYCH ZARZĄDZANIE STRATEGICZNE W SEKTORZE PUBLICZNYM
}

\section{Abstract \\ The Meaning of Accounting Instruments to Support Strategic Management in the Public Sector}

The purpose of the article is to indicate the importance of accounting tools that support strategic management in the public sector. The paper shows the growing role of management accounting instruments that can be used to make strategic decisions in public organizations. The development of strategic management is a prerequisite for improving the efficiency of the management and implementation of public tasks. Management can be effective only if it has the right set of useful information. One source of this knowledge may be the accounting system, especially management accounting. This article attempts to evaluate the problem by analyzing the literature and theoretical discussion.

Keywords: strategic management, management accounting, public sector.

\section{Streszczenie}

Celem artykułu jest wskazanie znaczenie narzędzi rachunkowości wspomagających zarządzanie strategiczne w sektorze publicznym. W opracowaniu zwrócono uwagę na rosnącą rolę instrumentów rachunkowości zarządczej, które mogą być wykorzystywane do podejmowania decyzji strategicznych przez podmioty sektora finansów publicznych ${ }^{1}$. Przeanalizowano znaczenie zarządzania strategicznego oraz dokonano charakterystyki rachunkowości zarządczej z punktu widzenia możliwości dostarczenia informacji niezbędnych w długoterminowym zarządzaniu organizacjami działającymi w sektorze publicznym. Rozwój zarządzania strategicznego

${ }^{1}$ Przez pojęcie jednostek sektora finansów publicznych należy rozumieć podmioty publiczne, a w szczególności jednostki wszystkich szczebli administracyjnych (jednostki samorządu terytorialnego, jednostki sektora rządowego), ale również takie podmioty, jak szpitale i ośrodki zdrowia publicznego, szkoły publiczne (w każdym stopniu kształcenia). 
jest warunkiem koniecznym do poprawy efektywności gospodarowania i realizacji zadań publicznych. Zarządzanie może być skuteczne tylko wtedy, gdy dysponuje odpowiednim zestawem użytecznych informacji. Jednym ze źródeł tej wiedzy może być system rachunkowości, szczególnie rachunkowości zarządczej. Niniejszy artykuł podejmuje próbę oceny wskazanej problematyki poprzez analizę literatury i dyskusję teoretyczną.

Słowa kluczowe: zarządzanie strategiczne, rachunkowość zarządcza, sektor publiczny.

\section{Wstęp}

W sektorze publicznym coraz większa uwaga skupia się na poprawie efektywności i skuteczności jego funkcjonowania². Podmioty publiczne oskarżane są o niegospodarność i nieefektywne zarządzanie mieniem publicznym. Poszukuje się nowych metod zarządzania i narzędzi wspierających funkcjonowanie jednostek sektora publicznego. Wprowadzane zmiany służą osiąganiu celów organizacji publicznych, zmierzających do poprawy efektywności działania całego sektora publicznego. Obserwuje się dostosowywanie instrumentów wykorzystywanych w sektorze prywatnym do wymagań sektora publicznego. Celem wprowadzanych zmian jest usprawnienie zarządzania w sektorze publicznym, co pociąga za sobą skuteczne działania w przepływie informacji, zwiększenie efektywności działania oraz podniesienie poziomu odpowiedzialności i rozliczania się z efektywności wykorzystywanych zasobów publicznych. Ponadto oczekuje się, że jednostki sektora publicznego będą kreowały wartości dla obywateli. Z jednej strony działalność organizacji publicznych związana jest z wypełnianiem ustawowych celów i spełnianiem oczekiwań swoich interesariuszy. Z drugiej efektywne działanie umożliwia osiąganie założonych rezultatów przy najmniejszym zużyciu zasobów albo przy danym poziomie zasobów generujących możliwie największą wartość dla odbiorców.

Zarządzający sektorem publicznym poszukują wiedzy i różnego rodzaju umiejętności, które są niezbędne do wykonywania procedur administracyjnych. Zmuszeni są również do podejmowania działań i decyzji zbliżonych do sektora komercyjnego, oczywiście uwzględniając specyfikę sektora publicznego. W polskim sektorze publicznym można odnotować wprowadzenie dwóch metod zarządzania - są to New Public Management (NPM) oraz Public Governance (PG) [Szumowski, 2014: 86-100]. W NPM, nowym zarządzaniu publicznym, zwraca się uwagę na stosowanie mechanizmów rynkowych, próbuje stosować reguły zbliżone do

${ }^{2}$ Pojęcie efektywności jest pojęciem złożonym. Za efektywne działanie można uznać takie, które pozwala na maksymalizację efektów przy określonym poziomie dostępnych środków lub minimalizację środków w celu uzyskania określonych efektów. Podmioty publiczne są zobowiązane do działania efektywnego, co szczegółowo określają przepisy ustawy o finansach publicznych. Efektywność w sensie ekonomicznym łączy się z pojęciem wydajności lub produktywności. Analiza wydajności (ang. productivity) może odpowiedzieć na pytanie: „Jak zwiększyć ilość usług dostarczanych przez podmioty publiczne, zmniejszając wydatki na te cele?”, za: Sześciło, 2017. 
podmiotów prywatnych, gdzie obywatel jest traktowany jako konsument usług publicznych. W PG, czyli partycypacyjnym zarządzaniu publicznym, określanym również jako współrządzenie, kładzie się nacisk na interesariuszy sektora publicznego (tj. obywateli, organizacje pozarządowe, przedsiębiorców), na dostęp do informacji, odpowiedzialność za wykonywane zadania oraz zrównoważony rozwój. PG jest podejściem szerszym w stosunku do zarządzania jednostkami publicznymi od NPM. NPM koncentruje się na redukcji kosztów oraz sprawności działania organizacji publicznej. PG zwraca większą uwagę na zdolności organizacji publicznej do zaspokajania potrzeb różnych grup interesariuszy. Obydwie metody zarządzania potrzebują odpowiedniego zestawu informacji. Jednostki publiczne poszukują niezbędnych informacji do podejmowania decyzji w zakresie efektywności wykonywanych zadań (usług) publicznych. Odpowiedni dostęp do informacji może zostać zapewniony przez informacyjny system rachunkowości. Przy tak określonych warunkach zarządzanie strategiczne nabiera znaczenia w długookresowym planowaniu działalności instytucji publicznych. Zarządzanie strategiczne staje się warunkiem koniecznym dla poprawy efektywności gospodarowania i realizacji zadań przez jednostki publiczne w dłuższym horyzoncie czasu.

Celem opracowania jest przedstawienie możliwości wykorzystania narzędzi rachunkowości zarządczej w zarządzaniu strategicznym, niezależnie od stosowanych metod zarządzania. W opracowaniu przedstawiono znaczenie zarządzania strategicznego dla podmiotów publicznych oraz dokonano charakterystyki narzędzi rachunkowości zarządczej z punktu widzenia możliwości dostarczenia informacji wykorzystywanej w zarządzaniu strategicznym.

\section{Znaczenie zarządzania strategicznego w organizacjach publicznych}

Zarządzanie strategiczne obejmuje uniwersalne sposoby skutecznego rozwiązywania problemów związanych z funkcjonowaniem organizacji, niezależne od ich typu. Zdaniem E. Wojciechowskiego, ,zarządzanie strategiczne to ukierunkowany na przyszłość proces planowania i wyboru celów oraz realizowanych zadań, wdrażania przyjętych postanowień, a także monitorowania i kontroli wykonania ustaleń" [Wojciechowski, 2003: 11-30]. Istotą zarządzania strategicznego podmiotów publicznych jest kształtowanie procesów rozwoju lokalnego i regionalnego oraz rozwiązywanie definiowanych problemów przez dłuższy okres czasu, przy zachowaniu racjonalnego i efektywnego gospodarowania posiadanymi zasobami. Zarządzanie strategiczne związane jest z selekcją priorytetów przyszłych działań w warunkach zmieniającego się otoczenia ${ }^{3}$. Problem polega na

${ }^{3}$ W literaturze wskazuje się, że organizacje publiczne muszę mierzyć się z turbulencją otoczenia, wynikającą z jego złożoności oraz jednocześnie nieprzewidywalności zmian zarówno w płaszczyźnie otoczenia ekonomicznego, jak i prawno-politycznego. Można byłoby tu wymienić w szczególności czynniki: polityczne, ekonomiczne, społeczne i technologiczne. 
wyborze priorytetów, zasugerowaniu, które cele są możliwe do osiągnięcia [Noworól, 2007: 143].

Na podstawie przeglądu literatury można wskazać najważniejsze cechy zarządzania określanego mianem strategicznego. Są to między innymi:

- świadome zarządzanie oparte na faktach związanych z kierowaniem rozwojem organizacji, nastawione na wykorzystanie szans i unikanie zagrożeń pojawiających się $\mathrm{w}$ jej otoczeniu, $\mathrm{z}$ uwzględnieniem wielu wersji planów strategicznych dla różnych scenariuszy i obszarów przyszłości [Rostowski, 2004: 17],

- zarządzanie oparte na strategicznym myśleniu i podejściu do funkcjonowania organizacji, charakteryzujące się oryginalnością, kreatywnością, chęcią stworzenia czegoś nowego oraz umiejętnością urzeczywistniania tego w sposób zwiększający efektywność i zapewniający konkurencyjność organizacji [Gawroński, 2010: 29],

- metoda podejścia do gospodarczych szans i wyzwań, związana z kompleksowym procesem zarządzania nastawionym na formułowanie i wprowadzanie w życie skutecznych strategii [Gryffin, 2005: 244].

Zarządzanie strategiczne jest determinowane dostarczanymi informacjami. Źródła informacji muszą być zróżnicowane, mają przedstawiać alternatywne możliwości, zwracające uwagę na przyszłe implikacje bieżących decyzji [Feszer, 2003: 161-176]. Kożuch uważa, że należy wydzielić zarządzanie strategiczne $\mathrm{w}$ organizacjach publicznych ze względu na odmienny charakter interakcji z otoczeniem, podsystem celów i wartości tego typu organizacji [Kożuch, 2004: 179]. Na odmienność zarządzania strategicznego składają się następujące mechanizmy [Gawroński, 2010: 32 i nast.]:

- miarą efektów zarządzania strategicznego jest dobro wspólne różnych interesariuszy, które może zostać ocenione niezależnie od poniesionych nakładów i podejmowanych działań w oddalonym czasie,

- koszty świadczonych usług publicznych mogą być oceniane jedynie częściowo w odniesieniu do ilości i jakości świadczonych usług,

- działalność organizacji publicznych jest regulowana prawem administracyjnym, a nie prawem własności,

- kierownictwo organizacji publicznych opiera się na zaufaniu publicznym (władze są wybierane w demokratycznych wyborach),

- organizacje publiczne nie mogą być oceniane na podstawie wymiernych wielkości ekonomicznych.

Zdaniem M. Żółkowskiego, „strategiczne zarządzanie instytucją publiczną związane jest $\mathrm{z}$ umiejętnością skutecznego i efektywnego rozwiązywania problemów poprzez formułowanie, a następnie realizowanie ustaleń strategii rozwoju oraz innych studiów, programów i planów działania danej organizacji” [Żółkowski, 2015: 154-155]. Umiejętność efektywnego rozwiązywania problemów w długookresowej perspektywie związana jest z realizacją cząstkowych zdolności, do których należy zaliczyć [Żółkowski, 2015: 154-155]: 
- identyfikowanie problemów,

- wielowariantowe podejście do rozwiązywania problemów i wybór optymalnego sposobu rozwiązania,

- wskazywanie realnych celów rozwoju i wybór problemów rozwojowych,

- racjonalne gospodarowanie środkami finansowymi, w tym wykorzystywanie zewnętrznych źródeł finansowania,

- wprowadzanie idei partnerstwa we współpracy z różnymi podmiotami,

- kreowanie pozytywnego wizerunku instytucji.

Głównym celem zarządzania strategicznego jest wskazanie długofalowych kierunków, pozwalających na wykorzystanie istniejących szans i czynników rozwoju. Zarządzanie strategiczne powinno być prowadzone zgodnie z określoną procedurą. Warto w tym miejscu wymienić zasady kształtujące zarządzania strategicznego. Są to [za: Ziółkowski, 2005: 103-108]:

- identyfikacja problemów (rozpoznanie i wskazanie najważniejszych problemów mających strategiczny wpływ na poziom zaspokojenia potrzeb społecznych oraz skalę procesów rozwojowych),

- kompleksowość rozwiązania problemów i traktowanie danej jednostki publicznej jako części otoczenia, które stanowi zbiór zarówno szans, jak i zagrożeń rozwojowych, a także determinuje osiąganie sukcesów w działaniu,

- orientacja na przyszłość, czyli rozwiązywanie bieżących problemów przez pryzmat przyszłości,

- orientacja na otoczenie organizacji, czyli maksymalne wykorzystanie szans i przeciwdziałanie zagrożeniom,

- orientacja na wyniki, czyli osiąganie celów poprzez systematyczną, skuteczną i efektywną realizację zaplanowanych wcześniej konkretnych zadań realizacyjnych,

- orientacja na kreowanie pozytywnego wizerunku organizacji.

Podstawowym zadaniem zarządzania strategicznego organizacji publicznych powinno być znalezienie, a następnie dokonanie wyboru optymalnych działań prowadzących do jak najlepszego zaspokojenia potrzeb zbiorowych danej wspólnoty. Niezależnie od stosowanych metod zarządzania, niezmiernie ważne jest tu ustalenie uwarunkowań zewnętrznych i wewnętrznych dla działań danej organizacji. Związane jest to $\mathrm{z}$ dostarczeniem odpowiednich danych i informacji niezbędnych do podjęcia decyzji.

W zarządzaniu w sektorze publicznym powinno kłaść się nacisk na oszczędności i efektywność posiadanych zasobów publicznych. Menadżerowie winni dokonywać racjonalnych wyborów na podstawie obiektywnych i rzeczowych analiz różnych wariantów decyzyjnych. Jednostki publiczne, zgodnie z nowymi trendami, muszą spełniać oczekiwania swoich interesariuszy, osiągając zamierzone rezultaty przy jak najmniejszym zużyciu zasobów, albo przy danym poziomie zasobów generując możliwie najwyższe wartości dla odbiorców swoich działań [Zarzycka, Michalak, 2013: 5-19]. W tak określonych warunkach niezbędne stają się dane i informacje umożliwiające podjęcie decyzji. Tu pomocne mogą być narzędzia $\mathrm{i}$ instrumenty stosowane $\mathrm{w}$ ramach rachunkowości zarządczej przez organizacje działające w sektorze publicznym. 


\section{Narzędzia rachunkowości wykorzystywane w zarządzaniu strategicznym organizacji publicznych}

Rachunkowość jest elementem informacyjnego systemu organizacji służącego wewnętrznym i zewnętrznym użytkownikom do podejmowania decyzji oraz rozliczania zarządzających z efektywnego i odpowiedzialnego gospodarowania powierzonym majątkiem [Jaruga, 1994: 8]. Warto w tym miejscu wskazać definicje rachunkowości. Zdaniem Jarugi, rachunkowość działa w zakresie „identyfikacji, pomiaru, przetwarzania oraz przekazywania informacji umożliwiających formułowanie opinii i decyzji przez jej odbiorców" [Jaruga, 1994: 8]. Dokonuje się tu rejestracji zdarzeń gospodarczych w sposób kompletny i wszechstronny, przy użyciu specyficznych metod, form i rozwiązań organizacyjnych oraz technicznych. Informacyjny system rachunkowości umożliwia przedstawienie jednostki organizacyjnej w sposób sformalizowany oraz wewnętrznie spójny i zbilansowany.

Zasady działania organizacji wpływają na sposób funkcjonowania i zadania rachunkowości. Działalność jednostek sektora publicznego jest określana zadaniami wyznaczonymi przez prawo, które to zadania poszczególne jednostki organizacyjne są zobowiązane wykonywać na rzecz swojej społeczności. Głównym źródłem pozyskiwania informacji w sektorze publicznym są sprawozdania, normowane przez różne przepisy prawne (np. Ustawę o rachunkowości, Ustawę o finansach publicznych, szczegółowe rozporządzenia dotyczące zasad rachunkowości i sprawozdawczości w sektorze publicznym oraz klasyfikacji budżetowej).

Sposób funkcjonowania jednostek publicznych wymaga od przyjętego systemu rachunkowości stosowania właściwych technik i metod w celu zaspokajania rosnących potrzeb informacyjnych zgłaszanych przez organy podejmujące decyzje finansowe i zarządcze. Zarządzający sektorem publicznym potrzebują danych umożliwiających sprawne zarządzanie jednostką i mieniem publicznym. Potrzebne są informacje dotyczące zarówno przeszłości, jak i przyszłości. Można zaobserwować dwoistość systemu rachunkowości w sektorze publicznym. Z jednej strony gromadzi on dużą ilość informacji przygotowywanych zgodnie z przepisami prawa, $\mathrm{z}$ drugiej agregowane dane nie umożliwiają podejmowania racjonalnych decyzji zarządczych, szczególnie dotyczących przyszłych działań. Menadżerowie poszukują nowoczesnych, bardziej skutecznych metod zbierania i analizowania danych, poprzez stosowanie narzędzi rachunkowości zarządczej. Rachunkowość zarządcza może wspomagać kierownictwo jednostek sektora publicznego w planowaniu, podejmowaniu i kontroli decyzji o charakterze operacyjnym i strategicznym. Rachunkowość zarządcza powinna stanowić narzędzie zapewniające efektywne i gospodarne wydatkowanie środków publicznych [Zarzycka, Michalak, 2013: 8; Adams, Muir, Hoque, 2014; Funnell, Cooper, 1998].

Korzystając z opracowania CIMA ${ }^{4}$ oraz E. Nowaka, warto wskazać, iż rachunkowość zarządcza ,jest traktowana jako integralna część zarządzania zajmująca

${ }^{4}$ CIMA (Chartered Institute of Management Accountants), www.cgma.org/principles 
się identyfikacją, prezentacją i interpretacją informacji wykorzystywanych: do formułowania strategii, planowania i kontroli działalności oraz ich dostarczania odpowiednim odbiorcom" [por. Nowak, 2015a: 403-410; Nita, 2015: 139-147]. Natomiast według Turyny, „rachunkowość zarządcza dostarcza informacje wspomagające menadżerów w procesach podejmowania decyzji, planowania ekonomicznego i kontroli realizacji planów" [Turyna, 2016: 545]. Rachunkowość zarządcza jest nastawiona na rozwój strategicznego zarządzania związanego z wyznaczeniem strategicznych kierunków działań, podejmowaniem decyzji i kontroli strategicznej. Zadaniem współczesnej rachunkowości zarządczej jest wspomaganie osiągnięcia strategicznych celów jednostki.

Rachunkowość zarządcza może być pomocna w formułowaniu przyszłych, szacunkowych wyników w procesie planowania i kontroli. Może być również wykorzystywana do porównywania rzeczywistych i planowanych wyników w celu analizy przyczyn niezrealizowanych zamierzeń. Zdaniem P. Bednarka, w rachunkowości zarządczej w jednostkach sektora publicznego powinno się zwracać uwagę na [Bednarek, 2007: 72-74]:

- dostarczanie informacji do celów planowania i programowania, zarówno w postaci szacunkowych danych o potrzebnych nakładach, jak i planowanych kosztach,

- analizę kosztów w różnych horyzontach czasowych,

- koszty ponoszone wśród różnych jednostek, powodujące koncentrację na pożądanych efektach i kosztach jednostkowych, oraz wyodrębnienie ośrodków odpowiedzialności za koszty,

- przeprowadzaną kontrolę, nie tylko z punktu widzenia kryterium legalności, ale również zgodności z wyznaczonym i pożądanym rezultatem (związane jest to między innymi ze sporządzaniem wewnętrznych sprawozdań umożliwiających kierownictwu analizę pomiędzy planowanymi i realizowanymi efektami),

- innowacje w zakresie informacji dostarczanej kierownictwu,

- gromadzenie informacji dla celów planowania i programowania w formie szacunkowych danych dotyczących kosztów w różnych przekrojach informacyjnych (płaszczyznach analizy),

- kontrolę działalności nie tylko z punktu widzenia legalności (formalno-prawnej), ale również zgodności z wyznaczonymi i pożądanymi skutkami realizacji zadań.

Wskazane elementy uzasadniają potrzebę wprowadzania instrumentów rachunkowości zarządczej. Rachunkowość zarządcza nie jest obligatoryjną częścią systemu rachunkowości prowadzonej przez instytucje publiczne ${ }^{5}$. Jednak coraz częściej narzędzia stosowane w sektorze prywatnym są wprowadzane i dostosowywane

${ }^{5}$ System rachunkowości zarządczej nie jest obligatoryjny, ale poszczególne narzędzia są wprowadzane do sektora publicznego. Celem opracowania było wskazanie narzędzi rachunkowości zarządczej wprowadzanych również nieświadomie (tzn. zarządzający mogą nie mieć świadomości ich stosowania w innych sektorach). Jedynie niektóre instrumenty są obligatoryjne dla poszczególnych podmiotów, np. budżet zadaniowy, wieloletnie prognozy finansowe. 
do potrzeb sektora publicznego. Dzięki temu organizacje publiczne mogą bardziej koncentrować się na realizacji zamierzonych celów, poprzez stosowanie analizy i planowania długookresowego.

W literaturze dostępne są opracowania dotyczące narzędzi rachunkowości zarządczej aplikowane w sektorze publicznym. Można znaleźć przykłady zastosowań narzędzi stosowanych w różnych instytucjach publicznych (samorządowych, rządowych), analizę tych instrumentów z punktu widzenia znaczenia dla wdrażanych koncepcji zarządzania. Z polskiej literatury warto wskazać opracowania Zarzyckiej i Michalaka [2013; 2017], Borowca [2011] oraz Mikulskiej [2011]. Jednak brak jest systematycznego przedstawienia instrumentów rachunkowości zarządczej wykorzystywanej w zarządzaniu strategicznym jednostek publicznych.

Zadania (usługi) publiczne wymagają celowego i trafnego doboru instrumentów oceniających realizację zaplanowanych działań. Organizacje publiczne mogą stosować narzędzia rachunkowości zarządczej w swojej działalności, wspomagając proces planowania strategicznego. Można tu wskazać następuję instrumenty [Mikulska, 2011]:

- strategiczna karta wyników,

- benchmarking,

- wieloletnie planowanie inwestycyjne,

- wieloletnie plany usług publicznych

- wieloletnie plany finansowe, wieloletnie prognozy finansowe,

- budżetowanie zadaniowe,

- rachunek kosztów,

- narzędzia zarządzania jakością usług (ISO, Best Value),

- wyodrębnienie środków odpowiedzialności,

- zabezpieczenie przed ryzykiem finansowym i prawnym.

W opracowaniu zwrócono uwagę na następujące instrumenty: strategiczną kartę wyników, wieloletnie prognozy i plany finansowe, rachunek kosztów, budżet zadaniowy oraz benchmarking ${ }^{6}$.

\section{Strategiczna karta wyników}

Instrumentem służącym do oceny i pomiaru dokonań w różnych obszarach działalności podmiotu jest strategiczna karta wyników, zwana również strategiczną kartą dokonań [Kaplan, Norton, 2006; Kowalewski, 2013: 113-124]. W przypadku tego instrumentu następuje wydzielenie różnych płaszczyzn analizy działalności organizacji. $Z$ jednej strony wskazuje się płaszczyzny ukierunkowane na świadczenie usług, obejmujące płaszczyznę procesów wewnętrznych, świadczenia usług i pracowników. $Z$ drugiej - formułuje podstawy do funkcjonowania podmiotów publicznych w przyszłości, poprzez płaszczyzny uczenia się, rozwoju oraz finansową [Skoczylas, 2011a: 236-250]. Celem strategicznej karty wyników

${ }^{6}$ Zdaniem autora, opisywane instrumenty są najczęściej wskazywane w literaturze oraz stosowane w polskim sektorze publicznym. 
jest wielopłaszczyznowa analiza zarówno wszystkich interesariuszy z punktu widzenia administracyjnego, jak i podmiotów korzystających z usług publicznych. Koncepcja ta jest oparta na systemie wskaźników, które dokonują pomiaru wyników działalności oraz zależności pomiędzy ilością i jakością świadczonych usług. Strategiczna karta wyników jest skutecznym narzędziem zarządzania długoterminowego, przy jednoczesnej analizie możliwości finansowych.

\section{Benchmarking}

Kolejnym narzędziem jest benchmarking, będący metodą systematycznego badania porównawczego. Koncepcja ta zakłada konfrontacje wykonywanych przez dany podmiot działań w stosunku do „najlepszego wzoru”. Przedmiotem porównania mogą być zarówno procesy, jak i funkcje w organizacji, kadra, usługi, zasoby finansowe i majątkowe, wartości postrzegane przez klienta [Mikulska, 2011: 429]. Wprowadzanie technik benchmarkingu sprzyja korzystaniu z dobrych praktyk innych instytucji, uczeniu się od podmiotów osiągających lepsze rezultaty, wprowadzaniu sprawdzonych wzorów postępowania.

\section{Rachunek kosztów}

Przedmiotem analizy następnej grupy narzędzi są koszty. Podmioty sektora publicznego stosują rachunek kosztów, którego zadaniem jest dostarczanie informacji niezbędnych do planowania działalności, podejmowania decyzji i kontroli przyjętych założeń w zakresie kosztów. W podmiotach publicznych można wyodrębnić dwa rodzaje kosztów składających się na całkowity koszt obsługi sprawy: koszty klienta oraz koszty obsługi sprawy. Przedstawiany rachunek kosztów może być uzupełnieniem stosowanego modelu rachunku kosztów w organizacjach publicznych. Informacje dotyczące kosztów powinny być tak prezentowane, aby umożliwić powiązanie kosztów z realizowanymi zadaniami budżetowymi oraz połączenie ich z przyczynami ponoszenia, łącznie z przypisaniem im określonych składników kosztów wyróżnionych w ramach obiektów odniesienia kosztów [Zackiewicz, Bucior, 2009: 413-416].

\section{Budżet zadaniowy}

Budżet zadaniowy umożliwia zaplanowanie celów podmiotu w powiązaniu z realizowanymi zadaniami, a następnie sprzyja realizacji zamierzonych celów. Wskazywany instrument daje podstawy do zarządzania działalnością organizacji publicznej poprzez wyznaczanie zadań, a nie tylko wskazywanie wielkości dokonanych wydatków i dochodów budżetowych. Dzięki temu organizacje publiczne mogą zarządzać z perspektywy realizowanych celów, poprzez analizę wykonywanych zadań. W budżecie zadaniowym stosuje się różne grupy wskaźników, 
dające podstawę do oceny realizowanych zadań. Do najczęściej stosowanych należy zaliczyć mierniki: produktu, rezultatu, oddziaływania, skuteczności, efektywności. Dostępność stosowanych wskaźników umożliwia ocenę podmiotów publicznych w różnych aspektach działalności [Skoczylas, 2011b: 174-186].

\section{Wieloletnia prognoza finansowa}

Wieloletnia prognoza finansowa stanowi instrument wieloletniego planowania finansowego, którego zadaniem jest ocena stopnia rozwoju danej jednostki w perspektywie kolejnych lat. Instrument ten obejmuje między innymi prognozy określonych danych, w szczególności dotyczące: dochodów i wydatków bieżących, w tym obsługę długu, gwarancje i poręczenia, dochody majątkowe, wynik budżetu, sposób przekazania nadwyżki lub finansowania deficytu budżetowego, przychody i rozchody budżetu, kwotę długu. Prognoza umożliwia analizę potencjału jednostki samorządu terytorialnego poprzez badanie skuteczność i efektywności podejmowania decyzji w zakresie gospodarki budżetowej (środkami publicznymi). Jest to obowiązkowy dokument sporządzany przez JST.

W Tabeli 1 przedstawiono syntetyczny opis poszczególnych instrumentów oraz przykłady zastosowania omawianych instrumentów w Polsce.

Tabela 1.

Przegląd instrumentów rachunkowości zarządczej aplikowanych w sektorze finansów publicznych

\begin{tabular}{|l|l|l|}
\hline Instrument & Znaczenie/ zastosowanie & Uwagi \\
\hline $\begin{array}{l}\text { Strategiczna karta } \\
\text { wyników }\end{array}$ & $\begin{array}{l}\text { Analiza pomiaru wyników i monitorowa- } \\
\text { nia efektów działania w czterech perspek- } \\
\text { tywach: finansowej, klienta, procesów } \\
\text { wewnętrznych oraz wiedzy i rozwoju. }\end{array}$ & $\begin{array}{l}\text { w różnych jednostkach pub- } \\
\text { licznych. Przykłady zasto- } \\
\text { sowania w Polsce: miasta } \\
\text { Tarnów i Lublin, gmina } \\
\text { Dobczyce, Goleniów, In- } \\
\text { nowrocław, Dzierżonów, } \\
\text { Hrubieszów. }\end{array}$ \\
\hline \multirow{5}{*}{ Budżet zadaniowy } & $\begin{array}{l}\text { Plan wydatków sporządzany w ukła- } \\
\text { dzie funkcji, zadań i podzadań wraz ze } \\
\text { wskazaniem na poziom zadań i podzadań } \\
\text { celów, które planuje się osiągnąc w wyni- } \\
\text { ku realizacji zadań/podzadań oraz mier- } \\
\text { ników określających stopień realizacji } \\
\text { celów. } \\
\text { Zarządzanie wydatkami poprzez efekty, } \\
\text { mierzone za pośrednictwem systemu } \\
\text { mierników. } \\
\text { Cel wprowadzenia: większa skuteczność } \\
\text { oraz efektywność i przejrzystość wydat- } \\
\text { kowania środków publicznych. }\end{array}$ & $\begin{array}{l}\text { Obowiązkowy dla jed- } \\
\text { nostek sektora finansów } \\
\text { publicznych. }\end{array}$ \\
\hline \multicolumn{2}{|l}{} \\
\hline
\end{tabular}




\begin{tabular}{|c|c|c|}
\hline Benchmarking & $\begin{array}{l}\text { Doskonalenie działań organizacyjnych } \\
\text { opartych na wyborze wzorcowej jednostki } \\
\text { i porównanie z nim własnej organizacji. }\end{array}$ & $\begin{array}{l}\text { Wykorzystywany na } \\
\text { różnych płaszczyznach } \\
\text { analizy. }\end{array}$ \\
\hline $\begin{array}{l}\text { Wieloletnia prognoza } \\
\text { finansowa }\end{array}$ & $\begin{array}{l}\text { Wprowadzana w formie uchwały; nad- } \\
\text { rzędne znaczenie w stosunku do budżetu. } \\
\text { Dokument strategiczny pozwalający } \\
\text { ocenić stopień rozwoju danej JST. } \\
\text { Cel: zwiększenie efektywności, wiary- } \\
\text { godności, jawności i przewidywalności } \\
\text { w gromadzeniu dochodów, przychodów } \\
\text { oraz ponoszenia wydatków i rozchodów } \\
\text { JST. }\end{array}$ & $\begin{array}{l}\text { Obowiązkowa dla jed- } \\
\text { nostek samorządu tery- } \\
\text { torialnego; szczegółowo } \\
\text { normowana w Ustawie } \\
\text { o finansach publicznych. }\end{array}$ \\
\hline $\begin{array}{l}\text { Rachunek kosztów } \\
\text { dzialań }\end{array}$ & $\begin{array}{l}\text { Wykorzystywany do modelu zarządzania } \\
\text { działaniami ABM (Activity Based Mana- } \\
\text { gement). } \\
\text { Koncepcja rozliczania kosztów na podsta- } \\
\text { wie związków przyczynowo-skutkowych } \\
\text { między zasobami, działaniami i kosztami. }\end{array}$ & $\begin{array}{l}\text { Przykłady wykorzystania } \\
\text { w szkołach wyższych oraz } \\
\text { zakładach opieki zdro- } \\
\text { wotnej. }\end{array}$ \\
\hline
\end{tabular}

Źródło: opracowanie własne na podstawie: Świerk, 2015: 471-484; Król, 2016; KaczurakKozak, 2013.

Wskazane instrumenty umożliwiają tworzenie systemu informacji niezbędnej do zarządzania podmiotami w sektorze publicznym. Zdaniem E. Nowaka, strategiczna rachunkowość zarządcza umożliwia pomiar dokonań jednostki o różnym charakterze. Nie może on ograniczyć się tylko do danych finansowych, musi obejmować także wielkości jakościowe decydujące o długookresowym realizowaniu zamierzonych celów [Nowak, 2015b: 216]. Jednostki sektora publicznego powinny stosować narzędzia strategicznej rachunkowości zarządczej, aby dostarczać informacje nie tylko o charakterze finansowym, wynikające z przepisów prawnych, ale również po to, by gromadzić dane jakościowe. Całościowe informacje jakościowe i ilościowe mogą być podstawą do strategicznego zarządzania organizacjami publicznymi.

Strategiczna rachunkowość zarządcza w sektorze publicznym powinna znaleźć zastosowanie między innymi [Nowak, 2015a: 211-224]:

- we wspomaganiu procesu zarządzania strategicznego,

- do oceny osiąganych długookresowych celów organizacji publicznych,

- w kreowaniu wartości dodanej dla odbiorców usług publicznych,

- do identyfikacji czynników kosztotwórczych o charakterze długookresowym,

- do poszukiwania danych o zasobach niematerialnych jako informacji o znaczeniu strategicznym dla organizacji publicznej,

- w analizie mierników niefinansowych w ocenie dokonań i realizacji zamierzonych celów. 


\section{Wnioski}

Współcześnie zarządzanie strategiczne powinno być warunkiem koniecznym dla poprawy efektywności gospodarowania i realizacji zadań przez jednostki publiczne. Jednostki publiczne poszukują informacji niezbędnych do podejmowania decyzji w zakresie efektywności wykonywanych zadań (usług) publicznych. Wprowadzanie instrumentów rachunkowości zarządczej może ułatwiać efektywną i skuteczną realizację zadań sektora publicznego. Stosowane narzędzia rachunkowości zarządczej w jednostkach publicznych w szczególności umożliwiają [Mikulska, 2011; Hood, 1991; Zawicki, 2011]:

- zwrócenie uwagi na tworzenie informacji niezbędnej do planowania strategicznego,

- kontrolę wykonywanych zadań, nie tylko z punktu widzenia legalności, ale również zgodności z wyznaczonymi celami i pożądanymi efektami,

- dostarczanie informacji kierownictwu w różnych płaszczyznach analizy, związanych nie tylko z wymogami formalnymi i sprawozdawczością wymaganą przepisami prawa,

- zwiększenie świadomości w zakresie kosztów i skoncentrowanie się na pożądanych efektach i kosztach, w połączeniu z ośrodkami odpowiedzialności,

- pomiar dokonań jednostki oraz orientację na rezultaty zamiast na nakłady,

- orientację na klientów (odbiorców usług) i dostarczanie dla nich wartości dodanej,

- kreowanie kultury organizacyjnej sektora publicznego.

Nowoczesna rachunkowość jednostek sektora finansów publicznych powinna być elementem zarządzania. Szczególnie rachunkowość zarządcza może być wykorzystywana do strategicznego zarządzania, niezależnie od wdrażanych metod zarządzania. Interesujące byłoby zbadanie przydatności zbieranych informacji pochodzących ze stosowanych narzędzi rachunkowości zarządczej.

\section{Bibliografia}

Adams C.A., Muir S., Hoque Z. (2014), Measurement of Sustainability Performance in Public Sector, „Sustainability Accounting, Management and Policy Journal”, vol. 5, iss. 1.

Bednarek P. (2007), Controlling w zarzadzaniu gmina, Polskie Wydawnictwo Ekonomiczne, Warszawa.

Borowiec L. (2009), Budżet zadaniowy jako instrument rachunkowości zarządczej w administracji centralnej [w:] Rachunkowość a controlling, pod red. E. Nowaka, Prace Naukowe Uniwersytetu Ekonomicznego we Wrocławiu, nr 56, Wrocław.

Feszer D. (2003), Strategiczne zarzadzanie jednostka samorzadu terytorialnego - istota, cele, etapy, „Studia i Materiały, Miscellanea Oeconomicae”, r. 17, nr 1, WZiA Uniwersytetu J. Kochanowskiego w Kielcach, Kielce. 
Funnell W., Cooper K. (1998), Public Sector Accounting and Accountability in Australia, UNSW PRESS, Sydney.

Gawroński H. (2010), Zarządzanie strategiczne w samorządach lokalnych, Oficyna Wolters Kluwer bussiness, Warszawa.

Gryffin R.W. (2005), Podstawy zarzadzania organizacjami, PWN, Warszawa.

Hood C.A. (1991), Public Management for All Seasons?, „Public Administration”, vol. 69, spring.

Jaruga A. (red.) (1994), Rachunkowość dla menedżerów, Towarzystwo Gospodarcze RAFIB, Łódź.

Kaczurak-Kozak M. (2013), Wdrażanie i konstrukcja budżetu zadaniowego w Polsce, PWSZ IPiA Studia Lubelskie TO IX Sulechów 2013, www.bibliotekacyfrowa.pl/Content/42711/009.pdf [dostęp: 28.05.2017].

Kaplan R.S., Norton D.F. (2006), Strategiczna karta wyników. Jak przełożyć strategię na działanie, PWN, Warszawa.

Kowalewski M. (2013), Adaptacja zrównoważonej karty wyników do specyfiki sektora publicznego - przypadek Kanadyjskiej Komisji Turystyki, PN UE we Wrocławiu, nr 287, Wrocław.

Kożuch B. (2004), Zarzadzanie publiczne w teorii i praktyce polskich organizacji, Wydawnictwo PLACET, Warszawa.

Żółkowski M. (2015), Strategiczne zarządzanie rozwojem gminy, „Ruch Prawniczy, Ekonomiczny i Socjologiczny", r. LXXVII, z. 1.

Król D. (2016), Ocena instrumentów zarządzania finansami samorząu terytorialnego $w$ świetle ewolucji paradygmatu finansów publicznych, „Nauki o Finansach”, 1(26), http://www.dbc.wroc.pl/Content/36634/Krol_Ocena_Instrumentow_Zarzadzania_Finansami_Samorzadu_2016.pdf [dostęp: 28.05.2017].

Mikulska T. (2011), Wykorzystanie narzędzi rachunkowości zarządczej do zarządzania finansami gminy, Zeszyty Naukowe Uniwersytetu Szczecińskiego, nr 668, Finanse, Rynki Finansowe, Ubezpieczenia, $\mathrm{nr} 41$.

Nita B. (2015), Globalne zasady rachunkowości zarządczej - próba standaryzacji, Zeszyty Naukowe Uniwersytetu Szczecińskiego, nr 854, Finanse, Rynki Finansowe, Ubezpieczenia, nr 73 .

Nowak E. (2015a), Instrumenty rachunkowości zarządczej wspomagajace realizację strategii przedsiębiorstwa, Studia i Prace Wydziału Nauk Ekonomicznych i Zarządzania, nr 39 , t. 4.

Nowak E. (2015b), Tendencje rozwoju systemu rachunkowości zarządczej, Zeszyty Naukowe Uniwersytetu Szczecińskiego, nr 873, Finanse, Rynki Finansowe, Ubezpieczenia, nr 77.

Noworól A. (2007), Planowanie rozwoju terytorialnego w skali regionalnej i lokalnej, Wydawnictwo Uniwersytetu Jagiellońskiego, Kraków.

Rostowski T. (red.) (2004), Nowoczesne metody zarzadzania zasobami ludzkimi, Difin, Warszawa.

Rozporządzenie Ministra Finansów z dnia 5 lipca 2010 r. w sprawie szczególnych zasad rachunkowości oraz planów kont dla budżetu państwa, budżetów jednostek samorządu terytorialnego, jednostek budżetowych, samorządowych zakładów budżetowych, państwowych funduszy celowych oraz państwowych jednostek budżetowych mających siedzibę 
poza granicami Rzeczypospolitej Polskiej, tekst jednolity z 2017 r., Dz.U. z 2017 r., poz. 760 .

Skoczylas W. (2011a), Mierniki monitorowania celów i zadań jednostki samorządu terytorialnego, Zeszyty Naukowe Uniwersytetu Szczecińskiego, nr 669, Finanse, Rynki Finansowe, Ubezpieczenia, nr 42.

Skoczylas W. (2011b), Strategiczna karta wyników w pomiarze osiągnięć jednostki samorzadu terytorialnego, Zeszyty Naukowe Uniwersytetu Szczecińskiego, nr 687, Finanse, Rynki finansowe, Ubezpieczenia, nr 48.

Sześciło D. (red.) (2017), Polityka administracyjna i zarządzanie publiczne, http://www.zna. wpia.uw.edu.pl/files/2013/11/podrecznik_calosc.pdf [dostęp: 1.12.2017].

Szumowski W. (2014), Zarządzanie publiczne - próba systematyzacji koncepcji, „Nauki o zarządzaniu. Management Sciences”, 4(21), Wydawnictwo Uniwersytetu Ekonomicznego we Wrocławiu, Wrocław.

Świerk J. (2015), Mapa strategii w działalności jednostek samorządu terytorialnego na przykładzie miasta Lublin, PN UE we Wrocławiu, nr 398, Wrocław.

Turyna J. (2016), Rachunkowość jako system informacyjny wspomagajacy zarzadzanie [w:] Nowe kierunki w organizacji i zarzadzaniu. Organizacje, konteksty, procesy zarzadzania pod red. B. Glinki, M. Kostery, Wolters Kluwer, Warszawa.

Ustawa o finansach publicznych z 27 sierpnia 2009 roku, tekst jednolity: Dz.U. z 2009 r., poz. 885.

Ustawa o rachunkowości z 29 września 1994 roku, test jednolity: Dz.U. z 2016 r., poz. 1870.

Wojciechowski E. (2003), Zarzadzanie w sektorze terytorialnym, Difin, Warszawa.

Zackiewicz B., Bucior G. (2009), Zarządzanie kosztami zadań budżetowych [w:] Problemy wspótczesnej rachunkowości, Uniwersytet Szczeciński, Zeszyty Naukowe nr 552, Finanse, Rynki Finansowe, Ubezpieczenia, nr 20, Szczecin.

Zawicki M. (2011), Nowe zarzadzanie publiczne, PWE, Warszawa.

Zarzycka E., Michalak M. (2013), Zakres i kierunki wykorzystania narzędzi rachunkowości zarzadczej w pomiarze dokonań w kontekście New Public Management-ujęcie instytucjonalne, „Zarządzanie Publiczne”, nr 4(26).

Zarzycka E., Michalak M. (2017), Potrzeby informacyjne menadżerów i pracowników jednostek sektora publicznego w kontekście New Public Management, http://dspace.uni.lodz. pl:8080/xmlui/bitstream/handle/11089/17498/16_377-396\%20Zarzycka\%20Michalak. pdf?sequence=1\&isAllowed=y [dostęp: 28.05.2017].

Ziółkowski M. (2005), Zarządzanie strategiczne w polskim samorządzie terytorialnym [w:] A. Zalewski (red.), Nowe zarzadzanie publiczne w polskim samorzadzie terytorialnym, SGH, Warszawa.

Ziółkowski M. (2015), Strategiczne zarządzanie rozwojem gminy, „Ruch Prawniczy, Ekonomiczny i Socjologiczny", R. LXXVII, z. 1, https/pressto.amu.edu.pl/index.php/rpeis/article/viewFile/938/822, [dostęp: wrzesień 2017]. 